\title{
Stigma experienced by men diagnosed with COVID-19
}

\author{
Estigma vivenciado por homens diagnosticados com COVID-19 \\ Estigma experimentado por hombres diagnosticados con COVID-19
}

\section{Anderson Reis de Sousa' \\ ORCID: 0000-0001-8534-1960}

Sheila Santa Barbara Cerqueira" ORCID: 0000-0002-3557-7200

Thiago da Silva Santana" ORCID: 0000-0003-0987-0814

Cleuma Sueli Santos Suto"' ORCID: 0000-0002-6427-5535

Eric Santos Almeida' ORCID: 0000-0001-9043-5988

Luana Santana Brito" ORCID: 0000-0002-7188-5497

Elena Casado'v ORCID:0000-0003-2940-9523

Evanilda Souza de Santana Carvalho" ORCID: 0000-0003-4564-0768

'Universidade Federal da Bahia. Salvador, Bahia, Brazil. "Universidade Estadual de Feira de Santana. Feira de Santana, Bahia, Brazil.

"'Universidade do Estado da Bahia.Salvador, Bahia, Brazil.

"Universidad Complutense de Madrid. Madrid, España.

How to cite this article: Sousa AR, Cerqueira SSB, Santana TS, Suto CSS, Almeida ES, Brito LS, et al. Estigma vivenciado por homens diagnosticados com COVID-19. Rev Bras Enferm. 2022;75(Suppl 1):e20210038. https://doi.org/10.1590/0034-7167-2021-0038

Corresponding author:

Anderson Reis de Sousa

E-mail: anderson.sousa@ufba.br

EDITOR IN CHIEF: Dulce Barbosa ASSOCIATE EDITOR: Hugo Fernandes

\section{ABSTRACT}

Objective: to analyze the stigma characteristics perceived in the experience of men who had COVID-19. Method: this qualitative study involved men living in Brazil, diagnosed with COVID-19, who answered semi-structured questions in an online form. Data were subjected to thematic and lexical analysis, interpreted in the light of the stigma theory. Results: 92 men, adults, cisgender, heterosexual, of mixed race/color, belonging to middle class, living in the urban area, with higher education participated. The stigma characteristics evidenced were the occurrence of leave, perception of impolite treatment, use of labels and discrimination by co-workers, family members, neighbors and even healthcare professionals, with consequences for the psycho-emotional dimension. Final considerations: discrimination and exclusion derived from stigma surprised men marked by class and gender privileges, little used to being downgraded in interactions when compared to other groups.

Descriptors: Social Stigma; Pandemics; Men's Health; Masculinities; COVID-19.

\section{RESUMO}

Objetivo: analisar as características do estigma percebidas na experiência de homens que vivenciaram a COVID-19. Método: estudo qualitativo, que envolveu homens residentes no Brasil diagnosticados com COVID-19, os quais responderam a questões semiestruturadas em formulário online. Os dados foram submetidos à análise temática e lexical, interpretados à luz da teoria do estigma. Resultados: participaram 92 homens, adultos, cisgêneros, heterossexuais, de raça/cor parda, pertencentes à classe média, residentes na área urbana, com nível superior. As características do estigma evidenciadas foram aocorrência de afastamento, percepção do tratamento descortês, aplicação de rótulos e discriminação advindas de colegas de trabalho, familiares, vizinhos e até mesmo profissionais de saúde, com consequências para a dimensão psicoemocional. Considerações finais: discriminação e exclusão derivada do estigma surpreenderam homens marcados por privilégios de classe e gênero, pouco habituados a serem rebaixados nas interações, quando comparado a outros grupos.

Descritores: Estigma Social; Pandemias; Saúde do Homem; Masculinidades; COVID-19.

\section{RESUMEN}

Objetivo: analizar las características del estigma percibido en la experiencia de hombres que experimentaron COVID-19. Método: estudio cualitativo con hombres residentes en Brasil diagnosticados de COVID-19, quienes respondieron preguntas semiestructuradas en forma online. Los datos fueron sometidos a un análisis temático y léxico, interpretados a la luz de la teoría del estigma. Resultados: participaron 92 hombres, adultos, cisgénero, heterosexuales, de raza/color morena, pertenecientes a la clase media, residentes en el área urbana, con educación superior. Las características del estigma evidenciadas fueron la ocurrencia de bajas, percepción de trato descortés, aplicación de etiquetas y discriminación derivada de compañeros de trabajo, familiares, vecinos e incluso profesionales de la salud, con consecuencias para la dimensión psicoemocional.Consideraciones finales: la discriminación y la exclusión derivada del estigma sorprendió a los hombres marcados por privilegios de clase y género, poco acostumbrados a ser degradados en las interacciones, en comparación con otros grupos.

Descriptores: Estigma Social; Pandemias; Salud de los Hombres; Masculinidades; COVID-19. 


\section{INTRODUCTION}

Stigma is understood as the depreciation of an individual or group of people who share certain socially devalued characteristics. The presence of the attribute that differentiates an individual or group from others causes them to be rejected, isolated, discriminated against and excluded from various activities that require social interaction. Moreover, individuals who do not have the characteristics, object of stigmatization, but live close to those who do, also suffer the same deprivations and labeling of the stigmatized, being the target of courtesy stigma ${ }^{(1)}$.

People diagnosed with COVID-19, during or even after complying with isolation measures, face social rejection, as they are avoided by others ${ }^{(2)}$, being targets of critical assessments and derogatory, in addition to having canceled invitations $s^{(3)}$. Those who work in essential services with greater exposure to the virus or contacted family members may also experience courtesy stigma $a^{(1-4)}$.

Epidemiological studies have shown that men are the individuals most affected by COVID-19; therefore, they may be more vulnerable to suffering the consequences of stigma. Some studies have only pointed out clinical aspects, without exploring factors related to masculinity and social phenomena that are involved in this new disease ${ }^{(5-6)}$.

Gender differences impact morbidity and mortality indicators between men and women, since the hegemonic model of masculinity in society determines that men must be strong, virile, courageous, providers and invulnerable, which affects the difficulty of adopting preventive care practices, such as social distancing, hand and object hygiene and the use of masks to prevent the contamination and dissemination of COVID-19, as well as the search of these subjects for healthcare services when they need specialized care when they present a symptomatological picture of the disease, placing this group in a situation of social and health vulnerability ${ }^{(7)}$.

In cases of emerging diseases with high mortality such as COVID-19, the fear of contagion, lack of knowledge and the absence of a vaccine for the entire population can motivate the discrimination of sick people and their contacts, as well as exclusionary behaviors, refusal to provide any type of service, harassment, intimidation, and aggressive attitudes ${ }^{(8-9)}$.

The stigmatized person may experience difficulties in accessing and continuing the available treatments, having their self-esteem declined, experiencing low efficacy, low satisfaction in activities of daily living, ostracism and psycho-emotional disorders such as depression ${ }^{(10-11)}$. Stigma potentiates psychological disorders, fears, uncertainties and behavioral changes ${ }^{(2,12-13)}$ and can prevent people with symptoms or diagnosis of COVID-19 from seeking healthcare services and contribute to a greater spread of the virus in the population.

Hiding the diagnosis by some people, for fear of stigmatization, can contribute to the worsening of the clinical condition, complications and limit the possibilities of reducing the spread, favoring transmissibility and mortality by the disease ${ }^{(9)}$, directly reflecting on the health system and on the epidemiological indicators of the pandemic ${ }^{(2-4)}$.

Reports on the effects of stigma were transmitted by healthcare authorities concerned about violence and the widening inequalities in access to services, in addition to warnings about the psycho-emotional and social consequences related to the disease ${ }^{(4)}$. Epidemiological data point to men as the population most affected by the pandemic. Evidence points to the influence of masculinities in health behaviors and in the production of vulnerabilities, which prompts further investigation; therefore, this study presents the following question: how does COVID-19 stigma have been expressed in the experiences of men who were infected?

\section{OBJECTIVE}

To analyze the stigma characteristics perceived in the experience of men who had COVID-19.

\section{METHOD}

\section{Ethical aspects}

This study observed all ethical recommendations and was approved by an Institutional Review Board (IRB), under CAAE (Certificado de Apresentação para Apreciação Ética - Certificate of Presentation for Ethical Consideration).

\section{Study design}

This is ananalytical, exploratory, qualitative study, derived from a matrix Project entitled "Vivências de homens em contexto de pandemia do novo coronavírus-Sars-CoV-2 (COVID-19) no Brasil: Um enfoque para a saúde", throught the secondary research entitled "Experiências de discriminação de homens que testaram positivo para a COVID-19".

\section{Study setting}

The survey was conducted through a virtual environment with the online form application hosted for free on Google Forms.

\section{Data source}

The study involved the participation of 92 adult men who were diagnosed with SARS-CoV-2, who were recruited from COVID-19 survivor groups.

\section{Data collection and production}

Data were collected from May to August 2020. Therefore, we used strategies to disseminate the research and approach participants on social networks such as Facebook', Instagram ", through the search for hashtags: \#euvenciaCOVID-19; \#euvenciaCOVID; \#euvencioCOVID-19; \#euvencioCOVID; \#euvenciocoronavirus and \#eutiveCOVID-19, which allowed access to membership groups in which invitations were sent in individual profiles and collective disclosure in them ${ }^{(14)}$. The consecutive recruitment technique called snowball smaplingwas adopted, structured from five seeds (key informants) distributed in the five regions of Brazil, concomitantly between the regions surveyed, which supported and disseminated to other possible participants ${ }^{(15)}$. 
Men who were adult and having a confirmed diagnosis for COVID-19 were included. There were no inclusion or exclusion criteria. After accessing the Informed Consent Form and confirming their consent, participants answered the form with structured sociodemographic and health data, and central and triggering open-ended questions, such as: have you experienced any remarkable situation that you considered to be discriminatory for having tested positive for COVID-19? Did you notice that you received any different treatment from people because you tested positive for COVID-19? By whom? Other triggering questions emerged, namely: did anyone ever use any nicknames or offensive words to address you because you tested positive for COVID-19? If yes, which ones did they use? What did they call you? Who acted to you this way? Did you notice any changes in people's behavior towards you? How have you reacted and/or have you reacted to this(these) situation(s) of discrimination? Such questions could be freely answered by the participants in the unlimited space provided in the online form.

The final sample was reached by adopting the theoretical data saturation criterion, which incorporated analysis of co-occurrences, convergences, complementarities and empirical data density. The collected data were organized and systematized in proper files for later coding.

The research team consisted of nurses and sociologist who performed hospital care, teaching and research activities during the research development.

\section{Data analysis}

Data were subjected to method triangulation through thematic analysis ${ }^{(16)}$ and lexical analysis. Initially, the text underwent exhaustive readings and re-readings. Then, attentive reading was carried out, line by line, with coding of data considered relevant for understanding the phenomenon. Each unit of analysis was reviewed in order to identify the existence of themes, pattern and coherence with subsequent grouping. After reviewing the themes, we sought to refine them and categories were defined and named. Then, for lexical analysis of the words, the text was processed in the software IRAMUTEQ (Interface of R pourles Analyzes Multidimensionalnelles de Textes et de Questionnaires) ${ }^{(17-18)}$ and Descending Hierarchical Classification (DHC) (17), from which was obtained the Dendrogram (Figure 1) that allowed observing the interrelationship between the speeches as illustrated by the relationships between the classes of words.

The results obtained from IRAMUTEQ ${ }^{\circ}$ indicate that $87.38 \%$ of the corpus was used, with the record of 2,018 co-occurrences and the cut-off point was frequency nine. Thus, in DHC, five classes of text segments emerged, which were named from the identification of the central ideas in each of the classes. At the end, the thematic and lexical analysis results were compared and the elaboration of the text was carried out, which gave a detailed examination of stigma in the face of its overlapping divisions, which are especially complex to identify in a large volume of data.

The empirical categories were validated by the research team in three virtual meetings. To interpret and understand the results, the Sociological Theory of Stigma was used from the use of the concepts of labeling, loss of status, removal, discrimination, which characterize perceived stigma ${ }^{(2,18-19)}$. To ensure quality, COREQ (Consolidated Criteria for Reporting Qualitative Research) guidelines were adopted.

\section{RESULTS}

The study included 92 men living in Brazil, with cisgender identity (76), heterosexual (41), of mixed race (42), followed by black (10); aged between 29 and 39 years old (36), single (39), completed higher education (57), with an average income above five minimum wages (36), living in urban areas (77), predominantly in northeastern Brazil (49), living with a partner (34). They mentioned complying with social isolation and reported using the Unified Health System (SUS - Sistema Único de Saúde) and private plans (33), followed by exclusively SUS (25). Most did not have chronic disease (56), and among those who reported illness, they mentioned asthma, diabetes (1), hypertension (3), hyperthyroidism (1), spinal cord injury (paraplegia) (1), obesity (1), HIV (3) and in compliance with quarantine (51) in the context in which the survey was conducted.

As shown in the Dendrogram (Figure 1), the words were grouped in a list and distinguished by size, separated by 552 text segments (TS), with the larger $\mathrm{ch}^{2}$, which expresses the strength of the link between shape and class. Thus, the more at the top and the greater its size, the more representative the word will have in the class composition. The disposition of the classes revealed that the material underwent, initially, three partitions resulting in three constituted categories, the first with classes one, the second category with classes two, three and four and the third with class five.

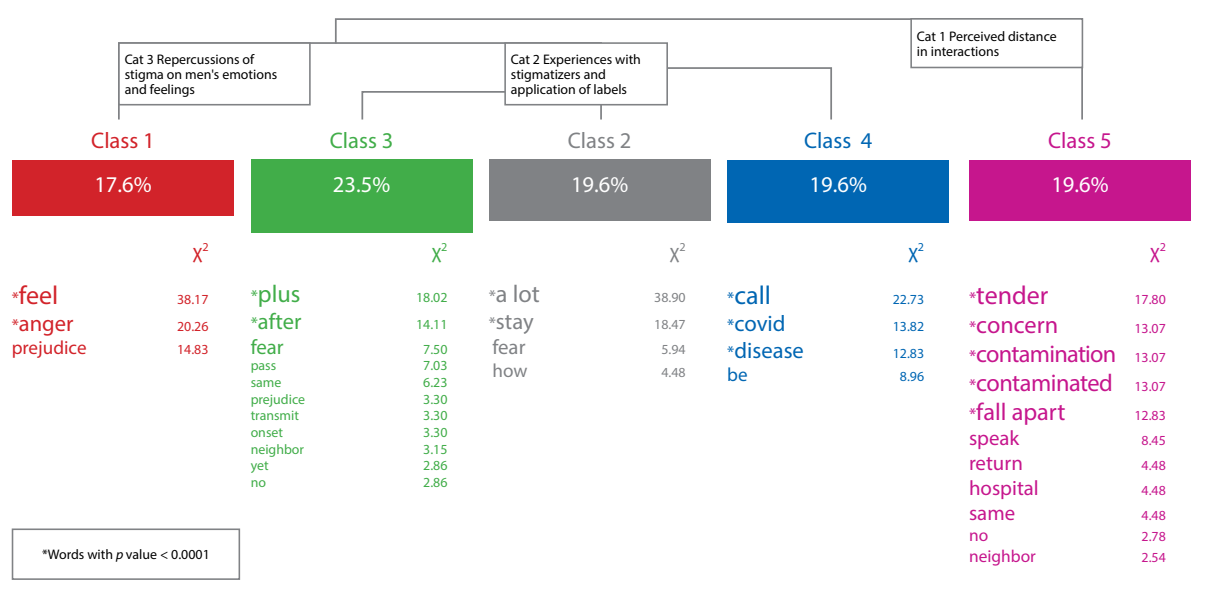

Figure 1 - Dendrogram with the percentage of Elementary Context Unitsin each class and words with the highest chi-square ( $\mathrm{X} 2$ ) provided byIRAMUTEQ ${ }^{\circ}$, Brazil, 2020 
Reading and interpretation were carried out from left to right and revealed that category 1: Perceived distance in interactions, composed of class five, gathers the highest frequency of terms with greater significance with $p$ value $<0.0001$, indicating what men experience during the illness process and the meaning attributed by them to the experience of withdrawal. The expressions most frequently include aspects that link the distancing of family members and health professionals to perceived prejudice. This category presents the centrality in the perception of distancing measures.

The second partition derived from category 2: Experiences with stigmatizers and application of labels, which comprises three classes two, three and four and brings elements that indicate the perception of discrimination based on fear of contagion, the depersonification of the infected person, greater visibility the disease and its viral agent, and annulment of the person. In this category, interactions with the significant subjects of stigma experience are evidenced.

The third partition originated category 3: Repercussions of stigma on men's emotions and feelings, encompassing class one and pointing to situations that triggered fears and feelings of anger derived from the experience of discrimination due to the disease.

\section{Category 1 - Perceived distance in interactions}

Frequent elements in this category were placed in only one class of the dendrogram, revealing its homogeneity and centrality in the stigma experience. In men's perception, the distancing stems from the fear of contagion of the disease, which is supported by uncertainty about the control measures and the virus transmission capacity, and which persists even after the beginning of treatment and cure.

Thus, upon realizing the existence of this distancing, men feel discredited by their peers, less valued by people from their social environment, such as co-workers, family members, neighbors and even health professionals.

In the face of removal actions, men perceive themselves exposed and vulnerable to others, which places them in the condition of "subject of risk" or "dangerous" that can threaten life and, therefore, should be avoided. There was both physical, geographic and institutional distance, as well as a rupture in communication and bonding. Proximity, then, is avoided, fearing the virus transmission and, consequently, of the evil that is intended to be avoided.

The distancing occurred not only in view of the illness, but in front of those who were in contact with the sick person or living in contexts with a high prevalence of the disease, due to the proximity to the phenomenon regardless of the diagnosis:

[...] the situation in the capital was more difficult, that's when I had to go to my hometown because of the progress of cases in the city where I live. When I arrived in the city, people were afraid to have contact with me. (E1)

[...]for living in a city that already had confirmed cases of COVID-19, and I decided to return to my hometown to be with my family, in order to feel more secure. Because I made this decision and was in transit from one city to another, I was exposed by the population. Contaminated. (E2)
[...] i suffered prejudice and in a way I was stigmatized by part of the population that was in voluntary quarantine, mentioning that I would be bringing the disease with me. People are afraid to get close, even after full recovery and no longer contaminating. All are afraid to take it, so people move away due to prejudice. (E3)

[...] / experienced the issue of prejudice for having suffered prejudice and the abandonment of my friends. Many people avoiding, ignoring.(E8)

[...] the neighbors noticed that I was not working and suspected the diagnosis.They became colder and more distant, for example: even each one in his house from their balconies, they did not greet or maintain eye contact. (E19)

[...] the neighbors no longer pass in front of the house and pass themselves by, they don't talk to me. (E25)

\section{[...] they blamed me for going to work. (E27)}

[...] exclusion even after healing. (E31)

[...] even though the period of contamination has passed, people are still away from me. (E40)

[...] i felt the rejection and aversion.Nobody wanted to approach. (E60)

Subjects' bodies began to be watched by themselves for symptoms and perceived themselves in constant assessment by the others. The men noticed differences in the modes of treatment received by colleagues, family members and especially neighbors, and believed that the contents of the communications could reveal aspects about COVID-19 diagnosis.

\section{Category 2 - Experiences with stigmatizers and applica- tion of labels}

This category is represented by elements from classes two, three and four and evidenced two subthemes/subcategories related to interactions with subjects situated by the participants as responsible for the stigmatization and the labels applied to the sick as a way of reference to their identity as a person with COVID-19. Subcategory 2.1 conforms to the perceptions of stigmatizers, and 2.2 specifies the labels assigned.

\section{Subcategory 2.1 - Men's perception of stigmatizers}

In this subcategory, participants reveal which subjects of their interactions positioned themselves as perpetrators of discourteous treatment, application of labels, speculation about their health/ disease condition, derogatory comments, blaming, separation and other measures of distancing. Among them, they mention friends, family, neighbors, service providers and health professionals:

[...] people acted with curiosity to know if I had the disease.(E10)

[...] i was very shaken because I heard many prejudiced words from people, which made me feel afraid of the distance.(E12)

[...] the application driver asked not to speak in the car.(E16) 
[...] after having fulfilled the isolation and starting to leave the house, I started to notice the looks were a lot of gossip.(E34)

[...] at the health post I was discriminated against by the professionals. They put me in an isolation room to receive care.(E35)

[...] when my neighbors found out that I returned from the hospital, even wearing a mask, and having been cured, they walked away from me when they saw me in the hallway, and I heard some whispers, just not hearing what they were saying.(E42)

[...] l experienced a lot of prejudice, whether with delivery professionals, family and friends. (E51)

[...] discrimination already starts by the health professionals themselves. (E61)

[...] yes, this virus is new, people are insecure about having contact with the fear of going against COVID-19.(E64)

[...] i felt despised even by my children.(E67)

[...] i suffered more in the work environment and for people in the community.(E70)

[...] yes, everyone has started to look at me with different eyes.(E81)

[...] when people get close to me, they immediately pick up the alcohol gel to pass them on and I know they want to hit me with this kind of attitude. (E90)

\section{Subcategory 2.2 - Application of labels}

Men perceived the erasure of their identity as their names were replaced and they began to be identified by labels attributed in connection with the virus or disease. Thus, they reflected the social reproduction of demarcation that tries to differentiate people who should be avoided because they are. The men then reported that they were called "pestilent, coronated, corona boys, plagued, contaminated":

\section{[...] contaminated.(E2)}

[...] at the hospital they didn't call me by my name, but by the name of the disease. (E6)

[...] calling me coronated.(E8)

[...] was a moment of great tension and insecurity, calling me coronated.(E14)

[...] look at the plagued [...] the corona boy.(E35)

[...] people in my building started to call me different by the disease name.(E42)

[...] they treated me as if I was with leprosy, always with much fear of me.(E43)

[...] i felt very sad because I never imagined that I could be accused of being contagious to people.(E44)

[...] friends called me chloroquinated.(E64)

\section{[...] i was called Mrs. COVID. (E67)}

[...] when I told people that I had the disease, they were shocked and asked me what I had done to be contaminated, as if I had some fault.(E69)

[...] ] suffered accusations that I was contaminating other people.I was nicknamed infected, here comes COVID-19 and even full of disease.(E70)

\section{Category 3 - Repercussions of stigma on men's emotions and feelings}

Given the perception of stigma, repercussions were perceived mainly in the psycho-emotional dimensions and social interactions, as evidenced in the content of class 1 of the dendrogram. Thus, when they felt discriminated against, men reported sadness, discouragement, anxiety, anger and hatred:

[...] i became shy.(E1)

it has been a very unpleasant situation, because in addition to the isolation of my family and other people close to me, I felt scared, sad and discouraged.(E3)

[...] i had a lot of concern. [...] was very difficult at first, as I didn't know how to deal with discrimination.(E13)

[...] these discriminations made me sad and led me to have emotional crises. I felt anger, anxiety, and the urge to explode at people and curse.(E14)

\section{[...] i felt angry.(E15)}

[...] prejudice and discrimination contributed to make me anxious and compromise my psychological state and even the recovery of my clinical condition, which took a long time to be reestablished due to the fact that it was disturbed and worsened.(E16)

[...] i was sad.(E23)

[...] i was afraid.(E26)

[...] it bothered me and affected me a lot. (E27)

[...] i was very scared and I confess that I ended up crying. (E31)

[...]it caused me revolt and left me very distressed.(E60)

[...] left my psychological state affected, making me feel angry and hateful because of people's prejudice.(E62)

[...] In my work I had difficulty accepting the Work Accident Report.(E68)

[...]most people did not believe that I had the disease.They doubted and that made me even more nervous and upset. (E89)

\section{DISCUSSION}

The rate of dissemination of COVID-19 as a disease with global reach, associated mortality, the absence of vaccines for the entire population and specific treatments required the adoption of social 
isolation to protect the entire population and quarantine those cases of people with suspicion or positive diagnosis ${ }^{(20-22)}$. Such measures implied an abrupt social distancing with a rupture of physical and emotional close relationships, which accentuated the perception of weakening bonds due to a distance adopted in the interactions.

The physical distance recommended as a measure to control the spread of the disease reinforced the distance between people and favored the construction of the notion of risk between sick and non-ill subjects. To the extent that this distance takes place, based on science and for protection purposes, are reproduced in parallel, marks of depreciation of subjects who tend to hurt their identity, limiting their transit in health services and in the protection network. In this sense, physical distancing reconfigures the notion of distancing in the experience of the stigmatized subject, as the public establishes the difference in which we are "the healthy ones" and they, the others are "the infected ones".

This categorization of subjects based on their characteristics occurs, according to Goffman ${ }^{(2)}$, due to the idealization that an individual or group must be or have to meet social norms, once contradicted, it recategorizes them as "abnormal", reduces them. the inferior to the others, they start to be recognized from the difference and removed from social life. This representation underlies the actions not only of separation of bodies, but also the rupture of bonds. Sanctions are then attributed to the "infected" regarding the spaces that their bodies can and must move ${ }^{(9)}$. Furthermore, the attribution of the brand (label) resists despite the finding of a cure, as the identity of a person with COVID-19 is already deteriorated and, thus, the sick are positioned as the "subject of risk". Uncertainties about the course of the disease and the impossibility of its definitive control maintain this social place of a dangerous and unwanted subject over the sick, making them enter a stigmatized career.

Stigma also emerged from the relationship with health professionals during care practices aimed at isolating and protecting. Although distancing measures are necessary within the health establishments, the communication of these measures when done in an authoritarian way makes the subjects attended to feel devalued ${ }^{(23)}$. Care practices can reproduce and reinforce the stigma at this time, when everyone feels threatened and is more vulnerable both physically and psycho-emotionally ${ }^{(24-25)}$ and when health professionals position themselves as both the target and perpetrators of stigmatization during the pandemic ${ }^{(8)}$.

In this study, labeling occurred when the stigmatizers used language resources, terms related to the disease or virus to refer to people, often applied in offensively. Thus, people diagnosed with COVID-19 gradually lost their identity and were treated based on stereotypes or metaphors surrounding the disease. In the case of men in particular, specificities arising from constructs of masculinities ${ }^{(7)}$ contributed to modeling the male public's own ways of perceiving and facing the disease and the phenomena present in stigma, such as, in the so-called male socialization spaces among friends and coworkers.

Stigma is characterized by the negative association of a person or group of people who share certain characteristics, such as those found in a specific disease ${ }^{(2)}$. In cases of outbreaks, epidemics or pandemics, directly affected people are labeled, stereotyped, discriminated against, isolated and treated differently by non-ill people, losing their social status ${ }^{(4,26)}$. Among men, labeling they can emerge subtly and even difficult to perceive, especially when combined with aspects of the attributes of hegemonic masculinity ${ }^{(7)}$, which diminishes and rejects masculine experiences in terms of sensitivity, emotions and feeling and the recognition of psychosocial impacts ${ }^{(9,26-27)}$.

Discrimination processes with stigmatizing characteristics were highlighted by participants, who reported suffering from the imposed distance, mistrust and attitudes that separate them from people and that remained even after the disease was cured. These findings corroborate those experienced by subjects affected by AIDS, tuberculosis, leprosy and the $\mathrm{H} 1 \mathrm{~N} 1 \mathrm{flu}^{(28-31)}$, whose deteriorating effects on the identity constructed in the social experience of the illness persisted over time. This may lead us to question whether discrimination related to the COVID-19 experience will be perpetuated as a social brand in the post-pandemic. How will this affect subjects' access to health services, especially rehabilitation services due to the disease sequel? How will these brands affect healthcare production?

In this study, men were surprised to be looked at, assessed and discriminated against, which are uncommon experiences in their group of belonging. The repercussions of the stigma related to COVID-19 were centered on the psycho-emotional dimension, reflecting on quality of sleep, the triggering of negative sensations and emotions. Such repercussions signaled the discomfort experienced by subjects positioned in privileged places in gender and class relations. Since COVID-19 arrived in Brazil, men have been identified as those who barely adhere to measures of social etiquette and hygiene, contribute to the spread of conspiracy theories that deny the existence of the virus and distance them from the possibility of illness ${ }^{(26-27)}$.

Studies involving people with HIV/AIDS and leprosy found that stigma brings immediate and late psycho-emotional repercussions to events, including the introjection of stigma itself, leading individuals to act in advance, as they predict that they will be treated by others, encouraging them to avoid rapprochement, with damage to the quality of social interactions and the maintenance of bonds ${ }^{(30-31)}$. The anticipation of stigma hinders the search for health services, either avoiding them or delaying their search, which may compromise treatment adherence and translates into significant barriers to adopting healthy behaviors and difficulty in achieving control over their own disease, leading to the advance of the outbreak ${ }^{(31)}$.

As seen in a study with people with tuberculosis, social isolation tends to remain after treatment, as well as the anticipation of stigma, when the sick person, based on their conceptions about the disease, harbors the fear of transmitting it to family members and other people around them ${ }^{(32)}$. But also, it tends to last due to the weakening of bonds, because in the face of infectious diseases, reactions of discrimination and prejudice overlap feelings and family and friendship ties ${ }^{(32-33)}$.

The experiences of stigma call the subjects to adopt strategies for coping with it, and, in the present study, men with COVID-19 assumed silencing, by omitting their health status to protect their identity in the expectation of not suffering discrimination and violence. This is because people are stigmatized based on 
the exposure of characteristics considered negative. In some disease processes, signs and symptoms are visible, making the subject discredited in face of the impossibility of manipulating information to hide the condition of being ill. However, there are diseases that place a sick person in an unbelievable position, when their condition is not apparent and makes it possible to choose between exposing or not their condition to others ${ }^{(2)}$. Thus, men with COVID-19 who did not present signs and symptoms of the disease that could be recognized as "COVID-19 patients" had the possibility of silence as a strategy to overcome the stigma surrounding the disease.

During the pandemic, the reasons for omitting the diagnosis seek to avoid loss of status in the positions occupied and would be related to threats of job loss, the survival of the individual and his group and the position of man seen as productive, useful, hardworking and provider, enhancing inequalities in access to employment. In the effects of stigma status reduction, stigmatized individuals are seen as less competent and with lower levels of influence and performance assessment ${ }^{(17)}$. These expectations and differentiation produce unequal results, differences in social and occupational opportunities, access to civil rights and health ${ }^{(34)}$.

The fear of being discriminated against, rejected, discarded from employment and isolated from social life in this study is similar to that experienced by people with HIV/AIDS and tuberculosis who also hide their diagnosis, and even avoid seeking care in services ${ }^{(30,32)}$. With regard to COVID-19, not all people with a confirmed diagnosis will present the same symptoms, some will even be asymptomatic, even though they can transmit the disease ${ }^{(35-37)}$. Thus, by not presenting visible or recognized attributes, these people can manipulate the information and reserve their diagnosis, discarding isolation measures and care to prevent the spread of the disease. These strategies, in the face of stigma, can lead the individual to successive re-exposure to the virus or expose other people to contagion, since the recognition of both symptomatic and asymptomatic subjects allows the delimitation of collective, individual and environmental care. Unlike HIV, whose transmission requires close contact, and the diagnosis can be kept in privacy without the need to restrict collective life, in COVID-19 transmission by airway can occur in public spaces with rapid spread of the disease; therefore, those affected should be encouraged to inform everyone about diagnosis and to adopt isolation in order to protect themselves from re-exposures and others, reduce the spread of the disease and avoid the collapse of the health system.

It is estimated that the pandemic will leave a balance of people who had COVID-19 in co-occurrence with other illnesses or stigmatizing conditions such as chronic diseases, disabilities or belonging to social minorities. In this sense, the intersectionality of stigmas can create barriers to access the necessary social and structural support and, consequently, widen health inequalities and intensify their experiences with stigma ${ }^{(37-38)}$.

The male population continues to show patterns of social behavior in health that reveal a higher prevalence of morbidity and mortality for other diseases and injuries ${ }^{(39-40)}$, as also occurs with COVID-19(41), as they present in their constructs of hegemonic masculinities, attributes that refer to "invulnerability", which in this case was relevant. By locating themselves in the population considered socially strong, men were silent in face of the impacts suffered or not by the stigma of COVID-19 in Brazil.

Men in Brazil often have difficulties in verbalizing feelings and emotions in unpleasant situations, which generate suffering and a threat to their psychosocial well-being, but which has shown prospects for changes with the advent of the COVID-19 pandemic ${ }^{(27)}$. This stems from the attempt to preserve socially constructed ideas that being a man is being strong, denying fragility and expressing power, honor and virility. And the experience of stigma could cause overlapping scratches in masculinities ${ }^{(26-27)}$. In this study, the perception of discourteous treatment and the application of difference and exclusion by a group of men with privileges and little discriminated against when compared to other groups was evidenced, which configures a specific marker to be recognized and explored among the male audience.

There is a variety of "social agents" who play a key role in the process of stigmatization and also in "de-stigmatization", including media professionals, employers, teachers, social service workers, police and health professionals, since the latter, although acting closer to the sick, are not immune ${ }^{(41)}$. The recognition of attitudes and practices that contribute to the reproduction of stigma and the identification of opportunities to promote the education of the population, especially men, who in earlier times already accumulate other vulnerabilities in health ${ }^{(41-43)}$, do part of the efforts for prevention and overcoming to be adopted by health professionals ${ }^{(40-45)}$. Based on the above, it is necessary to reinforce and recommend that attention be directed to COVID-19 survivors regarding emotional support, prevention, management and coping with the stress caused by stigma. Thus, the relevance of the re-elaboration of practices and interventions for the production of health care for men is emphasized, given the 'new', the pandemic socio-historical phenomena experienced by the male audience ${ }^{(26)}$.

The experience of adult men gained new contours with the pandemic phenomenon, and the emergence of a stigma related to the disease opened space for new and inexhaustible research fronts with a sociological lens on the public and private social interactions of these subjects, the presentation of themselves in daily life, gender roles, representations and care practice, interpretation of the disease and its implications on adherence to measures of prevention and treatment. Thus, this study contributes to deepening knowledge about the behavior of men on the borders between health and an emerging disease, strengthening the field of investigation about masculinities and men's health in the context of the pandemic.

\section{Study limitations}

Among the limitations of this study, we point out the exclusive use of an online instrument in data production, which restricted the recognition of stigma characteristics that would be possible with the use of techniques mediated by meetings and the prevalence of participants residing in northeastern Brazil. However, this methodology provided an opportunity for a class cut of participants that allowed access to experiences of stigma of a group historically and socially endowed with class and gender privileges, white men with higher education. 


\section{Contributions to nursing and health}

In the context of nursing, this study presents as relevant contributions the opening of space for the expansion of the production of Nursing care aimed at the male audience in the context of COVID-19. By typifying the stigmatizing agents and knowing the repercussions on the psycho-emotional dimension of the stigmatized, the findings can support care approaches that favor coping in the context of nursing practice. In addition, it will enable the expansion of investigations into the effects of stigma in the pandemic and post-pandemic periods.

The contributions of this study to health focus on highlighting the challenges in coping with COVID-19, adding scientific knowledge to the field of male health care and health discrimination, and the progress of the Brazilian National Policy for Comprehensive Care for Men's Health (Política Nacional de Atenção Integral à Saúde do Homem), implemented in Brazil. In addition, this study reveals its novelty in examining the phenomenon of the COVID-19 stigma in the Brazilian scenario, and allows the opening of a field of studies on the behavior of affected groups, supporting the formulation of therapeutic and social intervention policies and plans for prevent and address the consequences of the pandemic.

\section{FINAL CONSIDERATIONS}

This study sought to analyze the characteristics of stigma perceived in the experience of men who experienced COVID-19, evidenced in the experiences of withdrawal, labeling and discrimination. It is a pioneer in addressing the stigmatization of subjects with access to university education in the Brazilian context. Discrimination and exclusion derived from stigma surprised men marked by class and gender privileges, little used to be downgraded in interactions when compared to other groups. Consequences of stigma on the psycho-emotional dimension of participants such as sadness, discouragement, anxiety, anger and hatred were identified.

Investments to prevent stigma and minimize its effects on the psycho-emotional health of COVID-19 survivors require a multidisciplinary approach, in addition to considering the implications of this experience on therapeutic itineraries, access and care received in health services, self-care attitudes and family dynamics.

\section{REFERENCES}

1. Goffman E. Estigma: notas sobre a manipulação da identidade deteriorada. 4a edição. Rio de Janeiro: LTC; 1988.

2. Turner-Musa J, Ajayi O, Kemp L. Examining social determinantsof health, stigma, and COVID-19 disparities. Healthcare. 2020;8(2):168. https://doi.org/10.3390/healthcare8020168

3. Brooks SK, Webster RK, Smith LE, Woodland L, Wessely S, Greenberg N, et al. The psychological impact of quarantine and how to reduce it: rapid review of evidence. Lancet. 2020;39(5):10227. https://doi.org/10.1016/S0140-6736(20)30460-8

4. Word Health Organization (WHO). Considerations for quarantine of individuals in the context of containment for coronavirus disease (COVID-19): interim guidance[Internet]. 2020 [cited 2020 Aug 16]. Available from: https://apps.who.int/iris/handle/10665/331299

5. Kramer A, Kramer KZ. The potential impact of the Covid-19 pandemic on occupational status, work from home, and occupational mobility. J Vocat Behav. 2020;119:103442. https://doi.org/10.1016/j.jvb.2020.103442

6. Aggarwal S, Garcia-Telles N, Aggarwal G, Lavie C, Lippi G, Henry BM. Clinical features, laboratory characteristics, and out comes of patients hospitalized with coronavirus disease 2019 (COVID-19): early report from the United States. Diagnosis. 2020;7(2):91-6. https://doi. org/10.1515/dx-2020-0046

7. Medrado B, Lyra J, Nascimento M, Beiras A, Corrêa ÁCP, Alvarenga EC, et al. Homens e masculinidades e o novo coronavírus: compartilhando questões de gênero na primeira fase da pandemia. Ciênc Saúde Coletiva. 2021;26(1):179-83. https://doi. org/10.1590/1413-81232020261.35122020

8. Misra S, Le PD, Goldmann E, Yang LH. Psychological impact of anti-Asian stigma due to the COVID-19 pandemic: a call for research, practice, and policy responses. Psychol Trauma. 2020;12(5):461-4. https://doi.org/10.1037/tra0000821

9. Bagcchi S. Stigma during the COVID-19 pandemic. Lancet Infect Dis. 2020;20(7):782. https://doi.org/10.1016/S1473-3099(20)30498-9

10. Corrigan PW, Watson AC. Understanding the impact of stigma on people with mental illness. World Psychiatry [Internet]. 2002 [cited 2020 Dec 27];1(1):16-20. Available from: https://www.ncbi.nlm.nih.gov/pmc/articles/PMC1489832/

11. Cerqueira SSB, Brito LS, Freitas KS, Jenerette CM, Carvalho ESS. Tradução e adaptação transcultural da Sickle Cell Disease Health-Related Stigma Scale para o contexto brasileiro. Rev Baiana Enferm. 2019;33:e34572. https://doi.org/10.18471/rbe.v33.34572

12. Zaidi A, Ali AZ. Living under the shadow of a pandemic: the psychological challenges underlying social distancing and awareness raising. Psychol Trauma. 2020;12(5):508-10. https://doi.org/10.1037/tra0000815

13. Leão A, Lussi IAO. Estigmatização: consequências e possibilidades de enfrentamento em Centros de Convivência e Cooperativas. Interface Comun Saúd Educ. 2021;25:e200474. https://doi.org/10.1590/interface.200474

14. Nogueira ECD, Arão LA. Facebook como espaço de ação virtual: uma análise sobre as reações discursivas na fanpage de um movimento ambiental. Calidoscópio. 2015;(13):3:353-62. https://doi.org/10.4013/cld.2015.133.07

15. Patias ND, Hohendorff JV. Quality criteria for qualitative research articles. Psicol Estud. 2019;24:e43536. https://doi.org/10.4025/psicolestud. v24i0.43536 
16. Mendes RM, Miskulin RGS. A análise de conteúdo como uma metodologia. Cad Pesqui. 2017;47(165):1044-66. https://doi. org/10.1590/198053143988

17. Amaral-Rosa MP, Souza MAR, Wall ML, Thuler ACMC, Lowen IMV, Peres AM. Pontos a considerar quanto ao uso do software IRAMUTEQ na análise de dados qualitativos. Rev Esc Enferm USP. 2019;53:e03468. https://doi.org/10.1590/s1980-220x2019ce0103468

18. Camargo BV, Justo AM. Tutorial para uso do software IRAMUTEQ. Trends Psychol [Internet] 2016 [cited 2019 Feb 03];32. Avaliable from:http://www.iramuteq.org/documentation/fichiers/Tutorial\%20IRaMuTeQ\%20em\%20portugues_17.03.2016

19. Phelan JC, Lucas JW, Ridgeway CL, Taylor CJ. Stigma, status, and population health. Soc Sci Med. 2014;103:15-23. https://doi.org/10.1016/j. socscimed.2013.10.004

20. Link GB, Phelan JC. Conceptualizing Stigma. Ann Rev Sociol. 2001;27:363-385. https://doi.org/10.1146/annurev.soc.27.1.363

21. Lima DS, Alberto J, Leite D, Vinicius M, Araújo S, Aguiar AF, et al. Recommendations for emergency surgery during the COVID-19 pandemic. Rev Saude Cienc Biol. 2020;8(1):1-3. https://doi.org/10.12662/2317-3076jhbs.v8i1.3176.p1-3.2020

22. Pereira MD, Oliveira LC, Costa CFT, Bezerra CMO, Pereira MD, Santos CKA, et al. A pandemia de COVID-19, o isolamento social, consequências na saúde mental e estratégias de enfrentamento: uma revisão integrativa. SciELO Preprints. 2020. https://doi.org/10.1590/ SCIELOPREPRINTS.493

23. Reis-Filho JA, Quinto D. COVID-19, social isolation, artisanal fishery and food security: How these issues are related and how important is the sovereignty of fishing workers in the face of the dystopian scenario. SciELO Preprints. 2020;1-26. https://doi.org/10.1590/ SCIELOPREPRINTS.54

24. Ubaka CM, Chikezie CM, Amorha KC, Ukwe CV. Health Professionals' Stigma towards the Psychiatric III in Nigeria. Ethiopian J Health Sci. 2018;28(4):483-94. https://doi.org/10.4314/ejhs.v28i4.14

25. Almeida IM. Proteção da saúde dos trabalhadores da saúde em tempos de COVID-19 e respostas à pandemia. Rev Bras Saúde Ocup. 2020;45:e17. https://doi.org/10.1590/scielopreprints.140

26. Sousa AR. How can COVID-19 pandemic affect men's health? a sociohistoric analysis. Rev Prev Infec Saúde. 2020;6:10549. https://doi. org/10.26694/repis.v6i0.10549

27. Sousa AR, Carvalho ESS, Santana TS, Sousa ÁFL, Figueiredo TFG, Escobar OJV, et al. Men's feelings and emotions in the Covid-19 framing. Cienc Saud Colet. 2020;25(9):3481-91. https://doi.org/10.1590/1413-81232020259.18772020

28. Ribeiro MDA, Silva JCA, Oliveira SB. Estudo epidemiológico da hanseníase no Brasil: reflexão sobre as metas de eliminação. Rev Panam Salude Publica. 2018;42:e42. https://doi.org/10.26633/RPSP.2018.42

29. Maciel-Lima SM, Rasia JM, Bagatelli RC, Gontarski G, Colares MJD. A repercussão da gripe A (H1N1) nos jornais paranaenses. Hist Cienc Saud. 2015;22(1):273-91 https://doi.org/10.1590/S0104-59702015000100016

30. Chambers LA, Rueda S, Baker DN. Stigma, HIV and health: a qualitative esynthesis. BMC Public Health. 2015;15:848. https://doi.org/10.1186/ s12889-015-2197-0

31. Neiva RJ, Grisotti M. Representações do estigma da hanseníase nas mulheres do Vale do Jequitinhonha-MG. Physis. 2019;29(1):e290109. https://doi.org/10.1590/S0103-73312019290109

32. Craig GM, Daftary A, Engel N, O'Driscoll S, loannaki A. Tuberculosis stigma as a social determinant of health: a systematic mapping review of research in low incidence countries. Int J Infec Dis. 2017;56:90-100. https://doi.org/10.1016/j.ijid.2016.10.011

33. Fischer LS, Mansergh G, Lynch J, Santibanez S. Addressing disease-related stigma during infectious disease outbreaks. Disaster Med Public Health Prep. 2019;13(5-6):989-94. https://doi.org/10.1017/dmp.2018.157

34. Maleche A, Citro B, Tisile P, Abdullaev T. Measuring TB-related stigma. Int J Tuberc Lung Dis. 2017;1,21(11):4-5. https://doi.org/10.5588/ ijtld.17.0581

35. Hatzenbuehler ML, Phelan JC, Link BG. Stigma as a fundamental cause of population health inequalities. Am J Public Health (NY). 2013;103(5):813-21. https://doi.org/10.2105/AJPH.2012.301069

36. Zhu N, Zhang D, Wang W, Li X, Yang B, Song J, et al. A novel coronavirus from patients with pneumonia in China, 2019. N Engl J Med. 202;382:727-33. https://doi.org/10.1056/NEJMoa2001017

37. Monteiro LD, Franchi EPLP, Carvalho AAB. Projeções da demanda hospitalar do COVID-19 em relação às medidas de distanciamento social: estado do Tocantins. Rev Pat Toc. 2020;7(2):68-70. https://doi.org/10.20873/uft.2446-6492.2020v7n2p68

38. Jackson-Best F, Edwards N. Stigma and intersectionality: a systematic review of systematic reviews across HIV/AIDS, mental illness, and physical disability. BMC Public Health. 2018;18(1):919. https://doi.org/10.1186/s12889-018-5861-3

39. Beltrán-Sánchez H, Finch CE, Crimmins EM. Twentieth century surge of excess adult male mortality. Proc Natl Acad Sci USA. 2015;112(29):8993-8. https://doi.org/10.1073/pnas.1421942112

40. Moraes CT, Gotlieb LSLD. Mortalidade masculina em três capitais brasileiras, 1979 a 2007. Rev Bras Epidemiol. 2013;16(1). https://doi. org/10.1590/S1415-790X2013000100009

41. Conti P, Younes A. Coronavirus COV-19/SARS-CoV-2 affects women less than men: clinical response to viral infection. J Biol Regul Homeost Agents. 2020;34(2). https://doi.org/10.23812/editorial-conti-3 
42. Sousa AR, Queiroz AM, Florencio RMS, Portela PP, Fernandes JD, Pereira, A. Homens nos serviços de atenção básica à saúde: repercussões da construção social das masculinidades. Rev Baiana Enferm. 2016;30(3):1-10. https://doi.org/10.18471/rbe.v30i3.16054

43. Nyblade L, Stockton MA, Giger K, Bond V, Ekstrand ML, Mc Lean R. Stigma in health facilities: why it matters and how we can change it. BMC Med. 2019;17(25). https://doi.org/10.1186/s12916-019-1256-2

44. Villa S, Jaramillo E, Mangioni D, Bandera A, Gori A, Raviglione MC. Stigma at the time of the COVID-19 pandemic. Clin Microbiol Infect. 2020;(26):11,1450-1452. https://doi.org/10.1016/j.cmi.2020.08.001

45. Ferreira MS, Carvalho MCA. Contribuições da educação profissional na enfermagem para o enfrentamento da estigmatização associada aos transtornos mentais. Barbarói. 2020;56(1):127-40. https://doi.org/10.17058/barbaroi.v0i0.13281 